IRSH 58 (2013), pp. 395-428 doi:10.1017/S0020859013000485

(C) 2013 Internationaal Instituut voor Sociale Geschiedenis

\title{
From Class Solidarity to Revolution: The Radicalization of Arsenal Workers in the Late Ottoman Empire*
}

\author{
A KIN SEFER \\ Department of History, Northeastern University \\ 360 Huntington Ave, Boston, MA O2 I I s, USA \\ E-mail: sefer.a@husky.neu.edu
}

\begin{abstract}
This article introduces a bottom-up perspective to the history of the Revolution of 1908 in the Ottoman Empire by focusing on the experiences of workers in the Imperial Naval Arsenal (Tersâne-i Âmire) in Istanbul. Drawing mainly on primary documents, the article explores, from a class-formation perspective, the struggles and relations of Arsenal workers from the second half of the nineteenth century until the revolution. The Arsenal workers' involvement in the revolution was rooted in their class solidarity, which was revealed in a number of ways throughout this period. The workers' immediate embrace of the revolution was spurred by their radicalization against the state; such radicalization stemmed from the state's failure to solve the workers' persistent economic problems, and its attempts to discharge them and replace them with military labor. The case of the Arsenal workers thus points to the role of working-class discontent in the history of the revolution, a dimension that has thus far been only minimally addressed in Ottoman historiography.
\end{abstract}

\section{INTRODUCTION}

The Revolution of 1908 in the Ottoman Empire has long been characterized by the central role of organized officers in the army, who forced Sultan Abdulhamid II to reinstitute the Constitution and re-open the Parliament in July 1908. Popular participation in the revolution, however, is rarely mentioned, and such discussions tend to be restricted almost exclusively to the rebellions in various parts of Anatolia between

* I would like to thank Ilham Khuri-Makdisi, Timothy S. Brown, and Samuel S. Severson for their valuable comments and criticisms on the earlier drafts of this paper. I am also grateful to the anonymous referees and the Editorial Committee of the IRSH for their feedback, and to Özkan Akpinar and Aslı Orhon for their help during the research process. The translations from Ottoman Turkish throughout the text are my own. 
I905-I907 that remain both controversial and insufficiently studied. ${ }^{\text {I }}$ Recent labor history has seen significant attempts to illuminate, from a working-class perspective, especially the aftermath of the revolution, which was itself marked by various forms of labor unrest. ${ }^{2}$ However, an analytical class-perspective to the development of this unrest remains largely absent from the historical narrative. Indeed, the latter is still dominated by the activities of the Committee of Union and Progress (or "Young Turks" in general), who led and directed the rebellion in Macedonia, which precipitated the "Declaration of Liberty" (İlân-1 Hürriyet) on 23 July 1908. ${ }^{3}$

The most important reason for this silence, even among social/labor historians, is likely the implicit acceptance of the two-fold view that the revolution was prepared by the Young Turks - who were not, nor endeavored to be, a "popular movement" - and that direct linkage between the Young Turks and the workers must be shown in order to introduce the working classes into the narrative. Yet this exclusive concentration on the agency of the Young Turks does not explain why the Ottoman workers were so quick to embrace the Declaration of Liberty by immediately translating it into massive celebrations, widespread strikes, boycotts, and a blossoming of myriad political and non-political parties, unions, organizations, independent periodicals, and publications. If the Young Turks were not a popular movement, and if, prior to the revolution, there were only limited links between them and the working classes, then how should we explain the workers' massive involvement in the

I. For different views on the role of Committee of Union and Progress in these uprisings, see Aykut Kansu, 1908 Devrimi (Istanbul, 1996), pp. 35-96, and M. Şükrü Hanioğlu, Preparation for a Revolution: The Young Turks, I902-I908 (New York [etc.], 200I), pp. 9I-I 24.

2. Yavuz Selim Karakışla, “Osmanlı İmparatorluğu'nda 1908 Grevleri”, Toplum ve Bilim, 78 (1998), pp. I87-209; Y. Doğan Çetinkaya, 1908 Osmanl Boykotu: Bir Toplumsal Hareketin Analizi (Istanbul, 2004). Two recent investigations into Ottoman labor history that focus on the experiences of tobacco workers in this era are Can Nacar, "Tobacco Workers in Late Ottoman Empire: Fragmentation, Conflict and Collective Struggle" (Ph.D. Binghamton University, 2010) and E. Tutku Vardağlı, "Tobacco Labor Politics in the Province of Thessaloniki: Cross-Communal and Cross-Gender Relations" (Ph.D. Bogazici University, 20II.)

3. In fact, the point was highlighted almost three decades ago in a number of articles by Donald Quataert, who found in his research that "the revolution stemmed from the dislocations brought on by rising European economic penetration of Ottoman society and its economy"; D. Quataert, "Machine-Breaking and the Changing Carpet Industry of Western Anatolia, I860-1908”, Journal of Social History, I9 (1986), pp. 473-489, 483. See also his Workers, Peasants and Economic Change in the Ottoman Empire (Istanbul, 1993), esp. pp. 42-62, and Social Disintegration and Popular Resistance in the Ottoman Empire (New York, 1983). For a recent criticism of the dominant CUP-centric approach to the revolution, see Y. Doğan Çetinkaya, "I908 Devrimi ve Toplumsal Seferberlik", in Ferdan Ergut (ed.) II. Meşrutiyet'i Yeniden Düşünmek, (Istanbul, 2010), pp. 13-27.

4. Hanioğlu, Preparation for a Revolution, p. 6. 
revolutionary festival following 23 July? In order to understand this unusual phenomenon in Ottoman history, we must first historicize the revolution from a bottom-up perspective.

The Declaration of Liberty was immediately embraced by the working classes of Ottoman society, who launched a wave of massive strikes a week after the Declaration was announced. The workers' quick and collective response in adopting the revolution and actively seizing this opportunity to promote their own cause can be effectively understood only by examining previous traces of the workers' collective consciousness and their radicalization against the government throughout the preceding decades. By the eve of the revolution, the workers had already formed a collective solidarity through their struggles and this, in fact, was what enabled them immediately to put their mark on the revolution.

The history of struggles between the state and the workers in the Imperial Naval Arsenal (Tersâne-i Âmire) in Istanbul affords a useful case study for presenting how this solidarity formed along class lines and how it affected the workers' response to the Declaration of Liberty. Despite the heterogeneity of their backgrounds (that is, places of origin, skills, wages, and workplaces), and the absence of institutional settings (for example, guilds and unions) that could have facilitated their engagement with each other, the Arsenal workers managed to mobilize their shared experiences and cultural practices on behalf of their class solidarity. In other words, the workers' collective solidarity, which had emerged during the decades before the revolution, is crucial in explaining the continuity of their struggles in the periods before and after the Declaration and their immediate participation in the revolution.

The term "class solidarity" is not used here merely for rhetorical purposes. Examining the experiences and relations of Arsenal workers in a historical process will illustrate that these experiences and relations evidenced class patterns. As E.P. Thompson explains in his seminal work, understanding these patterns is only possible by surveying them over "an adequate period of social change". The history of the workers of the Imperial Arsenal provides ample evidence of this class-formation process. Although this article concentrates mostly (but not exclusively) on the economic dimension of the process - primarily owing to reliance on state documents which generally concerned wage problems - it also recognizes the necessity of further research into other (i.e. ethno-religious) dimensions. ${ }^{6}$

5. E.P. Thompson, The Making of the English Working Class (New York, 1966), p. I I.

6. A critical problem in studying the Ottoman working classes, which has been discussed by other labor historians as well, unfortunately also presents itself here. In exploring the lives of working-class people, the necessary reliance on state documents inevitably limits the scope of their actions into a "resistance-against-the-state" narrative. In such readings, these people could become a "subject" of these governmental correspondences only when they posed "threats" or 
Thus, focusing exclusively on one of the most active working-class communities in the late Ottoman Empire, this study also aims to engage the historiography of Ottoman labor, particularly by presenting ways in which the process of class formation functioned in Ottoman history, and discussing the central role of workers in the history of the Ottoman Revolution of 1908 .

\section{THE IMPERIAL NAVAL ARSENAL AND ITS WORKERS}

The Imperial Naval Arsenal of the Ottoman Empire, located in Istanbul, underwent a modernization process throughout the nineteenth century; by the I 870 s it had become a major industrial complex, with several largescale workshops and various small factories. ${ }^{7}$ The Arsenal was a site not only for the construction and maintenance of naval ships, but also for production of various manufactured goods, ranging from smelted iron to weapons. Thousands of soldiers, officers, and civil servants worked in the facilities; civilian workers and artisans were also employed, both for their artisanal skills and sometimes to meet labor shortages in short-term projects, such as construction and maintenance.

The workers and artisans were, depending on their backgrounds and skills, distributed among several factories and workshops within the complex. These facilities housed a wide range of tasks, from the construction and maintenance of vessels to the production of various machines, guns, and other materials needed for the ships and the army in general. At times, each of the factories employed hundreds of workers.

"problems" for the state authority. An ideal way to overcome this problem is to locate and focus on "ego-documents", which this article endeavors to do via analyses of petitions from the workers. However, it should be noted that although the practice of petitioning had a long history in the Ottoman Empire and was widely used by ordinary people as a means of voicing their discontent, the original copies of many petitions were not preserved to evidence the summaries of them made by officials in their correspondence. Naturally, these summaries necessarily reflect the concerns and selective perspectives of the officials, and do not allow us to hear the actual voices of the petitioners. In effect, this has been one of the reasons why studies about petitions and petitioning have been scarce, despite some recent attempts. See, for example, E. Gara, C.K. Neumann, and M.E. Kabaday1 (eds), Popular Participation and Political Resistance in the Ottoman Empire: Studies in Honor of Suraiya Faroqhi (Istanbul, 20I I), especially the chapters in "Part I: Petitioning Practices". Although this article presents examples from original petitions that were discovered in the course of research, a significant portion of the sources concerning the workers, their discontents, and their actions comes from state correspondence. Therefore, in many cases we shall have to extract the workers' voices and actions only through "seizing the documents by the throat", as Deringil put it in a different context. See S. Deringil, "The Study of the Armenian Crisis of the Late Ottoman Empire, or, Seizing the Document by the Throat", New Perspectives on Turkey, 27 (2002), pp. 35-59.

7. See A. İhsan Gencer, Babriye'de Yapulan Islahat Hareketleri ve Babriye Nezareti'nin Kuruluşu (Istanbul, 1985). 




Figure I. Workers in the boiler shop in the late nineteenth century. Workers were distributed throughout various workshops and factories in the Imperial Naval Arsenal.

Library of Congress, Prints E Photographs Division, Abdul Hamid II Collection,LC-USZ6281725 . Used with permission.

This was especially the case during the reign of Sultan Abdulaziz (I86I-I876), whose pursuit of the ambitious project of creating one of the world's largest navies placed the Arsenal at the very center of this endeavor. In $\mathrm{I} 87 \mathrm{I}$, the ironworks employed 284 workers, the machine factory 257 , and the repair factory 347 . Besides factory workers, there were also sizeable numbers of workers in artisanal jobs, such as carpenters, masons, tinsmiths, and painters, as well as lesser-skilled laborers, including porters and construction workers. ${ }^{8}$ The size of this working community dramatically decreased after the severe economic depression of the mid-I870s. Nevertheless, civilian workers remained central to the production process throughout the following decades.

Although these employees differed widely in terms of their backgrounds, qualifications and/or technical expertise, they were all categorized under

8. For a list of those facilities with the number of their workers, see Şakir Batmaz, "II. Abdulhamit Devri Osmanlı Donanması" (Ph.D. Erciyes University, 2002), pp. I27-I 28. 
the term amele (worker) throughout Ottoman government correspondence. Even foreign "masters" (master craftsmen and tradesmen) who were brought to the Arsenal for their skills and expertise were denoted by this term. ${ }^{9}$ However, this was not always the case in the workers' selfperceptions. For example, a petition sent to a newspaper during the economic crisis in 1873 was signed by the "poor carpenters and workers of the Arsenal", which suggests that at least some qualified artisans did not identify themselves as "workers". ${ }^{10}$ Nevertheless, as this and other collective actions of the era suggest, this distinction remained semantic, especially as it did not lead to any disparities that would have otherwise prevented the workers from acting together against the state for their collective interest.

Indeed, by the revolution in 1908 , the workers had come to identify themselves as işçi or amele, each of which corresponds to the term "worker", regardless of their backgrounds and artisanal skills. The texts of the petitions presented by the Arsenal workers in this period do not differentiate between skilled and unskilled workers. A roster of the names, places of origin, and jobs of fifty-eight unemployed workers who signed a petition as "Arsenal workers" lists many skilled and unskilled workers (for example, carpenters and construction workers) together; likewise, neither the petitions nor the related correspondence make any distinction between the workers with artisanal skills. Hence, even this differentiation within the workers' self-perceptions appears to have been discarded within three decades.

Subsuming their differences in pursuit of a common identity was likely a challenging process, for such divergences were not limited only to the workers' skills. Because the Arsenal was a large and heterogeneous complex rather than a single specific workplace for a particular undertaking, workers were distributed among different tasks throughout various workshops and factories. Although recent studies have highlighted specific industry-related examples where kinship and common homeland played a central role in workers' mobilization, ${ }^{\text {I }}$ these factors do not seem to have exerted a similar influence at the Arsenal, primarily due to the heterogeneity of the production processes there. ${ }^{\mathrm{I} 2}$ Although there were

9. Prime Ministry Ottoman Archives, [hereafter BOA] Y.PRK.ASK. $53 / 63$.

ı. Hadika, no.54, 26 Zilkade I289 (25 January i 873), p. I.

I I. M.E. Kabaday1, "Working in a Fez Factory in Istanbul in the Late Nineteenth Century: Division of Labour and Networks of Migration Formed along Ethno-Religious Lines", International Review of Social History, 54 (2009), Supplement 17, pp. 69-90.

I2. In a notable instance, a report from 1906 on the leaders of striking workers mentions their different occupations (i.e. workers from the boiler shop and the power plant as well as a carpenter), and their different homelands (i.e. Sivas, Ankara, Kemah, and Istanbul); BOA.Y.MTV $285 / 57$. 
indeed workers who came from the same homelands, the overall workforce at the Arsenal remained highly heterogeneous in terms of places of origin. Moreover, the workers did not maintain a union, guild, or any other such institution which would have facilitated their networking. As such, the distinctive nature of the production processes posed a serious obstacle to their collective mobilization, especially after the dissolution of Parliament in 1878 , when government intolerance against any form of contentious collective actions increased significantly.

Aside from their problems with the state, these workers were also united by common experiences in their daily lives. The previously noted petition emphasized that the workers had "worked loyally" for thirty to forty years as "Muslims from rural districts" to sustain their poor families still living there. ${ }^{\mathrm{I}}$ Many workers had the chance to work together within the same complex, if not in the same workshop or factory, for decades, especially after the failure of the government's attempts to discharge civilian workers. Although the workers were from different places, most were migrant workers from rural districts and had left their families behind. As with other migrant workers in the capital, the Arsenal workers probably lived in khans (wayside inns) and in neighborhoods around the complex.

Unfortunately, specific information about their lives outside the Arsenal is lacking. It is known, however, from government correspondence which negatively mentions it, that they met and spent many hours in coffee houses near the Arsenal. These spaces likely allowed them to discuss the common problems and anxieties of their daily lives. Such concerns were hardly limited to problems with their wages. Indeed, being a migrant worker was itself a source of unease, not least as the Ottoman government rarely hesitated to "return" workers to their homelands when they became vocal about their problems. Sometimes the workers' voices synchronized into common protest through religious festivals and holy days, when they expected to be paid (as was traditional) and often needed to spend extra money for their families and rituals. That the majority of these workers belonged to a common religion facilitated their use of Islamic festivals and holy days as an arena for struggle throughout these years.

All of these shared experiences provided a solid basis for their mobilization against a common target, and not only because the Arsenal remained part of the Naval Administration during this period. Of course, that the government was also the workers' employer had much to do with why their discontent was directed at state authorities; however, this situation was more complex than it may appear. The Imperial Arsenal, as a military institution critical to the government, was never allowed to be 
autonomous but instead was always maintained as a specific niche within the larger schemes of the Ottoman rulers. The government always adopted a direct, "hands-on" attitude towards the Arsenal and its workers; such policies ranged from the introduction of universal conscription and efforts towards industrial modernization to enthusiastic policies for establishing a powerful navy, the management of financial crises, and social control of the population.

At the same time, especially in the Hamidian period, the state was endeavoring to boost its influence and visibility in daily affairs, particularly through the Sultan's efforts to increase the "personal, paternalistic, and unbureaucratic" character of his power. ${ }^{14}$ By means of welfare policies and symbolic practices that especially targeted the poor, Sultan Abdulhamid II expanded his personal power at the expense of the bureaucracy. His policies and practices also enabled the workers to mobilize collectively against government bureaucracy, which they held responsible for their suffering. ${ }^{\text {Is }}$ In this way, the Sultan's policies became the precise areas whereby the class solidarity of Arsenal workers developed and materialized. Before examining these areas, however, we must first understand the history of the workers' acrimonious relations with the government.

\section{THE MILITARIZATION OF THE LABOR FORCE AND ITS FAILURE}

Despite their employment being a significant necessity for the government, the civilian workers in the Arsenal were a source of various economic and social problems for the authorities. Being hired from outside the navy, they were more costly in comparison with the working sailors. ${ }^{16}$

I4. Nadir Özbek, "Imperial Gifts and Sultanic Legitimation during the late Ottoman Empire, 1876-1909", in M. Ener, A. Singer, and M. Bonner (eds) Poverty and Charity in the Middle Eastern Contexts (New York, 2003), pp. 203-220, 206.

I 5 . In effect, this seems to be why, despite celebrating the revolution and the end of "tyranny", Arsenal workers and the general Ottoman population did not have an explicit goal to overthrow the Sultan. This detachment of the ruler from the rest of the state bureaucracy can be seen in other cases as well. For instance, in his study on the Iranian revolution, Asef Bayat shows that the urban poor engaged in a "parallel struggle" to change their own lives without necessarily aiming at overthrowing the Shah, who was viewed "as outside of their day-to-day troubles". See Asef Bayat, Street Politics: Poor People's Movements in Iran (New York, 1997), p. 39.

I6. Occasionally, the government ordered the master artisans who produced rifles in the provinces (such as Macedonia and Mosul) to be brought to the Arsenal, in order to isolate them from the local rebels. See BOA.DH.MKT.2467/48, BOA.DH.MKT.2521/102, and BOA.Y.PRK.BŞK.3 I/90. A British newspaper reported that skilled workers in the Arsenal were paid from 2s. -5 s. a day (by comparison, British engineers working there were paid I3s. a day); Pall Mall Gazette, "The Industrial Classes in Turkey”, 26 January I872. In I 906 an Ottoman official determined that the daily wages paid to civilian and military workers were generally around $\mathrm{I}_{4}$ kuruş and 3.5 kuruş respectively; BOA.Y.MTV.285/57. 
Moreover, they were more difficult to discipline and had to be kept under constant surveillance as they were not a part of the hierarchical military order. The Ottoman authorities commonly referred to them as başıbozuks (unruly), a term often used to refer to irregulars who worked for the army (in both combatant and non-combatant roles) but did not belong to the army hierarchy.

Therefore, it is not surprising that, in the wake of the conscription system introduced in the I840s, one of the government's initial attempts was to replace these workers in the Arsenal with cheaper and more disciplined military labor recruited from throughout the Empire. Indeed, in I85 I, the government decided to recruit non-Muslim soldiers into the Naval Arsenal, to replace the başıbozuk workers. ${ }^{17}$ Initially, the non-combatant character of military service in the Arsenal was thought to be especially attractive to nonMuslims, who had become disenchanted with the new system of universal conscription owing to it now including Muslims and non-Muslims alike. It was also an ideal option for the government, given its lack of enthusiasm for conscripting non-Muslims into combat forces. Yet in the I850s the policy failed in the wake of widespread resistance from non-Muslims against the new system of conscription. ${ }^{18}$ As a result, non-Muslims were granted the right to exemption from military duty via a special tax. ${ }^{19}$

This failure did not deter the authorities from seeking to militarize the labor force in the Naval Arsenal. The system of universal conscription remained to be institutionalized, however, mostly because of opposition from local populations who resisted the new policy by violent reaction or simply by evading conscription. ${ }^{20}$ More important, however, was the government's dilemma regarding this militarization. Even when conscripts were brought to the Arsenal to join the labor force, they often turned out to be untrained for their jobs and unskilled. And although they could be trained in the Arsenal over a period of years, they were supposed to be released after their terms of duty concluded. This was a highly obvious source of inefficiency in the operations of the Arsenal's various workshops and specific shipbuilding projects. The need for a skilled, trained, and experienced workforce was most acute after the i 860 s, when Sultan Abdulaziz launched his ambitious campaign to build a large and powerful naval force for the Ottoman Empire. ${ }^{2 I}$ However, this project

17. Ufuk Gülsoy, Osmanli'nın Gayrimüslim Askerleri (Istanbul, 2010), p. 56.

I8. Ibid., pp. 56-58.

19. Erik Jan Zürcher, “The Ottoman Conscription System, I844-1914”, International Review of Social History, 43 (1998), pp. 437-449, 444.

20. For a number of case studies on the instances of resistance against conscription, see Eric Jan Zürcher (ed.), Arming the State: Military Conscription in the Middle East and Central Asia, I775-1925 (New York [etc.], 1999).

21. Batmaz, "II. Abdulhamit Devri Osmanlı Donanması", p. I 27. 


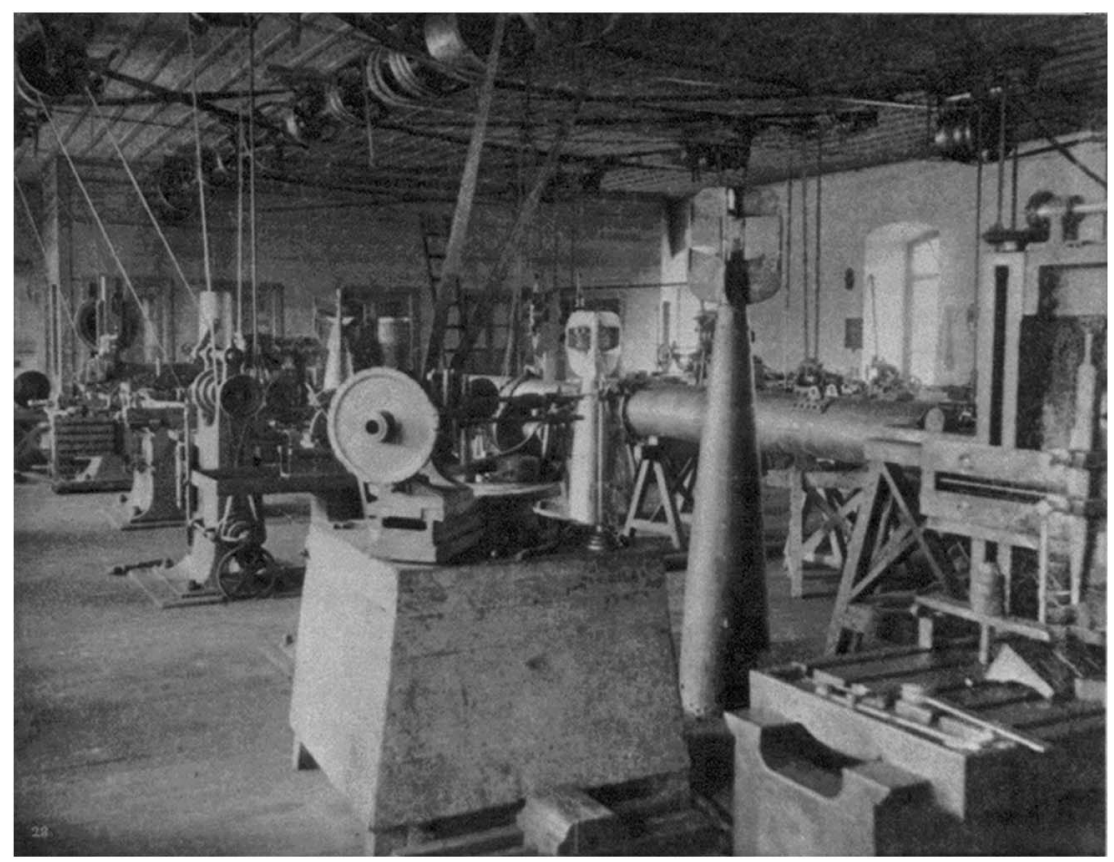

Figure 2. The torpedo factory in the Arsenal. The Imperial Naval Arsenal became one of the epicenters of industrial modernization throughout the nineteenth century.

Library of Congress, Prints E Photographs Division, Abdul Hamid II Collection, LC-USZ628I72I. Used with permission.

necessarily depended on skilled master craftsmen and workers hired from outside the conscription system, who could remain employed in the Arsenal for as long as the projects continued. During the years following, the Sultan would eventually come to favor the efficiency of the existing working process in the Arsenal over the hope of creating a less costly and more disciplined labor force.

From the mid-century on, the palace's keen appetite for developing the navy would be further whetted, especially thanks to British credit, and enabled by British engineers, master craftsmen, and workers invited to contribute to this goal. New and expensive machines were bought to the Arsenal, and several facilities and workshops were built for the construction of powerful ironclad ships for the navy. These developments required not only larger numbers of workers, but also workers with the particular skills and abilities to operate the new machines and workshops and to supervise these projects. By the 1870 , these efforts had yielded a certain degree of success: the Ottoman navy was now considered to be "the third in strength in the whole world" (after Britain and France). 
This achievement was often presented by the British press as a "British" accomplishment in the Ottoman Empire. ${ }^{22}$ However, the presence of foreign workers in the Arsenal posed further problems for the Ottoman authorities. British employees earned more than native workers, and not paying them regularly risked not only harming relations with the British government but also tarnishing the prestige of the Ottoman government. The public, especially in Britain, read news about British workers in Istanbul whose wages had been in arrears for several months. The eruption of the global financial crisis in the early i 870 s rendered it far more difficult for the Ottoman government to obtain loans from the European markets, and the British workers soon became an even more pressing financial burden for the Arsenal.

In 1873 , the government began gradually to discharge the British master craftsmen and artisans by not extending their contracts with the Arsenal. The authorities were convinced that native workers had now reached the necessary levels of technical knowledge and skills no longer to need supervision from the British. ${ }^{23}$ Of course, British newspapers did not share the same confidence, and complained about the dismissals. ${ }^{24}$ As the number of discharged British workers increased with the worsening economic crisis in the mid-I 870 s, a British journalist, ostensibly infuriated by the Ottoman government's plan to replace its British employees with native workers, concluded that the Imperial Arsenal, "like so many other unlucky attempts at European civilization under Ottoman rule, must be pronounced a failure". ${ }^{25}$

The following years witnessed a dramatic decrease in the number of British workers, yet foreign workers did not disappear entirely from the Naval Arsenal. Throughout the Hamidian period there remained a need for the expertise and skills of foreign craftsmen and workers, albeit less so than previously. However, parallel to the improving diplomatic relations with Germany (which had occurred at the expense of Britain) during this era, the profile of the foreign labor force was becoming increasingly diversified, and now included German workers alongside British ones. In I 896, for example, the number of German workers nearly equaled that of the British. ${ }^{26}$ Yet, even with such minimal numbers of foreign workers,

22. The Standard, "The Turkish Iron-Clad Fleet", 2 January I 87 I, and "Turkey: The Imperial Arsenal at Haskeui", i I February i87i; Western Times, "Turkey in Europe: Sailing of the Turkish Fleet under an English Admiral”, I 2 July i 876.

23. The Morning Post, "Turkey", 22 November I 873.

24. Ibid.

25. The Star, "English Colonies on the Bosphorus", 26 February i 876.

26. Of 25 foreign workers, I I were British and 9 were German. See Kaori Komatsu, "I 896'da Osmanlı Bahriyesi'nde Yabancilar ve Gayri Müslimler”, Tarih ve Toplum, I39 (1995), pp. 16-22, 20. 
the problems that hampered payment of wages did not recede. In I 896, a British newspaper warned British citizens planning to leave for jobs in the Imperial Arsenal that workers there had not received payment for several months and were thus facing serious economic difficulties. ${ }^{27}$ The same year, nine German workers in the Arsenal collectively resigned because their wages had been in arrears for months. ${ }^{28}$

Although in the I 890 os occasional voices within the bureaucracy argued for the reliability of native workers, the Ottoman government did not completely forgo its reliance on foreign master craftsmen, and still made occasional attempts to recruit professionals from abroad to supervise new projects in the Arsenal. ${ }^{29}$ Localization of the labor force, however, was not the ultimate goal and solution for the government. The financial crisis deteriorated severely in the 1870 , leading to the declaration of a moratorium in 1875 . This intensified the pressures on the authorities to institute a far more efficient state of management in the Naval Arsenal, as well as a better disciplined and more obedient labor force. Yet, civilian workers demonstrated forcefully that they could not be kept silent in the face of growing economic hardship. The workers of the Naval Arsenal were severely impacted by the economic crisis, with their wages falling into arrears for such long periods that it became a major challenge to cope with the unfavorable economic conditions. ${ }^{30}$ Their restlessness was evinced by a number of massive strikes during this period. ${ }^{3 \mathrm{I}}$

In January i 873 , 500-600 Muslim and non-Muslim workers of the Arsenal went on strike, having not received their wages in I I months. ${ }^{32}$ They marched together to the Sublime Porte (Bâb-1 Âli), the government complex that housed the Grand Vizierate and other main government offices, and

27. Aberdeen Journal, "British Workmen in Turkey: A Warning", 8 June 1896.

28. Batmaz, "II. Abdulhamit Devri Osmanli Donanması", p. is I.

29. Ibid., pp. I $52-154$.

30. For a contemporary account which describes the misery of Arsenal workers and workers in general, underlining how "the anger" among the poor was connected to plots against the government, see Pall Mall Gazette, "Affairs at Constantinople", is March i 876. Indeed, two and a half months later Sultan Abdulaziz was toppled as a result of one such plot.

3I. Strikes also occurred in other sectors during this period. For an overview of workers' collective actions in the Ottoman Empire throughout the nineteenth century, see Yavuz Selim Karakışla, "The Emergence of the Ottoman Industrial Working Class, I839-1923", in D. Quataert and E.J. Zürcher (eds), Workers and the Working Class in the Ottoman Empire and the Turkish Republic, I839-1950 (London [etc.], 1995), pp. 19-34, and Cevdet Kirp1k, "Osmanlı Devleti’nde İşçiler ve İşçi Hareketleri (I876-I9I4)" (Ph.D. Süleyman Demirel University, 2004).

32. It should be noted that this did not always mean that they had worked without pay for consecutive months during the entire period. Rather, it sometimes included the total number of unpaid months from the previous year(s) as well. Nevertheless, as details about these unpaid months were not always clearly expressed, it sometimes led to confusion even among the bureaucrats, as revealed in their correspondence on the issue. 
presented a petition to the Grand Vizier. A few days later, this time joined by their mothers and wives, the workers attempted to present a collective petition during the Friday Prayer Ceremony (Cuma Selamlığı). ${ }^{33}$ They were stopped by the police and, after a violent clash with these forces, were eventually dispersed. However, this did not discourage the workers, who also sought to make their voices heard in the press. In one such petition dispatched to a newspaper, the workers complained about their desperate conditions and requested that the newspaper publicize their dire circumstances and organize an aid campaign for them. As if to demonstrate the workers' despair, the same days also witnessed riots by Arsenal workers, who "plundered" the rations of naval officers. The workers' anger, it seemed clear, could only be appeased by paying them their long-overdue wages. ${ }^{34}$

The disparity between the demands of the Arsenal workers and the financial restraints of the government led to other strikes and collective actions. The strikes continued throughout the following years, and reached their peak in the spring of 1876 , when 2,000 workers went on strike, joined by their wives. ${ }^{35}$ Although this strike, as with previous ones, was resolved through financial compensation to the workers, it led the authorities to opt for immediate militarization of the labor force. Soon, almost I,000 workers were dismissed from the Arsenal, with the intention of replacing them with conscripted sailors from the navy. This measure was actively applauded by the British press. One correspondent, reporting the dismissals, encouraged the Ottoman authorities to extend the scale of this militarization to encompass all infrastructural projects across the Empire. This would, according to the correspondent, help to accelerate and reduce the costs of efforts to modernize the less developed parts of

33. In the Ottoman Empire, the Sultan's attendance at Friday Prayers was a ceremonial, during which subjects were given the opportunity to present their petitions to him. About Friday Prayer ceremonies in this era, see Mehmet İpşirli, "Osmanlılar'da Cuma Selamlığı: HalkHükümdar Münasebetleri Açısından Önemi”, in Prof. Dr. Bekir Kütükoğlu'na Armăgan (Istanbul, I 991) pp. 459-47I.

34. Hadika, no. 54, 26 Zilkade I 289 (25 January I 873), pp. I-2. See also Oya Sencer, Türkiye'de İş̧i Sinıfi:Doğuşu ve Yapısı (Istanbul, 1969), pp. I35-137. The newspaper was banned for two months after this coverage, on the basis of "perturbing the minds": see Hadika, no. 57, 30 Muharrem I 290 ( 30 March I 873), p. I.

35. Sencer, Türkiye'de İşi Sinffi, pp. I40-I4I. The occasional and collective involvement of women alongside their husbands in labor struggles offers a glimpse into the formation of workers' discontent and solidarity, not only on the shopfloor but also in the household. Further research on the everyday lives of workers and their relations to the larger society will allow us to "make women visible to labor history", as Balsoy puts it, through examining their roles not only in the production process, but also in the everyday lives of male workers. For a recent study on women factory workers in Ottoman Istanbul, see G. Balsoy, "Gendering Ottoman Labor History: The Cibali Régie Factory in the Early Twentieth Century", International Review of Social History, 54 (2009), Supplement 17, pp. 45-68. 


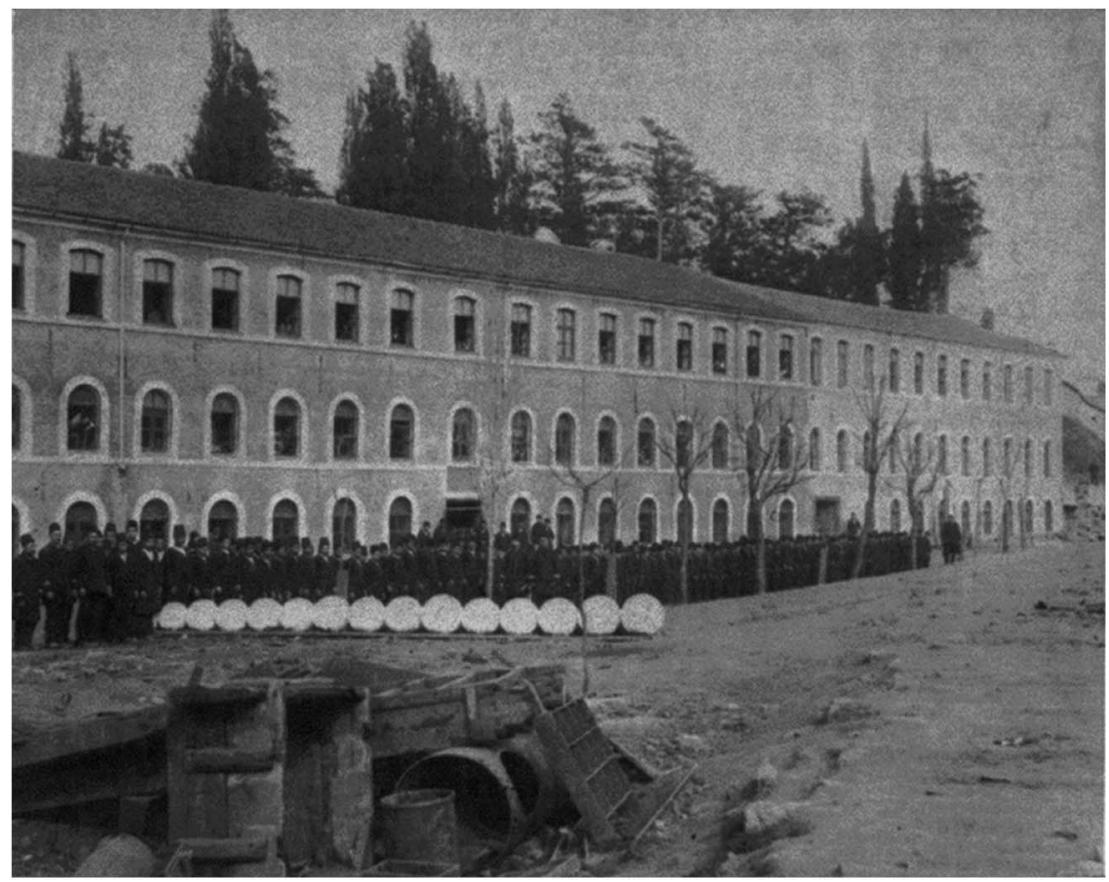

Figure 3. The Boys' Battalions were introduced to overcome the problems associated with the militarization of labor in the Naval Arsenal.

Library of Congress, Prints \& Photographs Division, Abdul Hamid II Collection, LC-USZ6281707. Used with permission.

the Empire, such as the Armenian regions in the eastern provinces. ${ }^{36}$ Even after the massive dismissals, a civilian workforce still remained in the Arsenal. This was largely due to a crucial dilemma that the Ottoman authorities had contended with since the mid-century: even as they were seeking ways to establish a cheap yet disciplined labor force, they also desperately needed workers with the necessary technical skills and experience and who could be employed without time restrictions. Hence, the same tumultuous period which witnessed large-scale dismissals as well as persistent collective actions by the workers also saw many of the remaining workers assigned to permanent status. In February 1876 , in response to petitions from the Arsenal workers, these more experienced workers were granted permanent status and were registered into insurance funds. ${ }^{37}$

36. The correspondent also mentions that "the same parsimonious plan has already been tried" at the Imperial Armory (Tophâne-i Âmire) in Istanbul, and "will probably be also continued there"; Western Times, "Turkey in Europe", I 2 July i 876.

37. BOA, İ.DH.717/50103. 
This dilemma was the subject of a series of special reports and correspondences submitted to the palace in I882. The reports of the Naval Council (Şûrâ-i Bahriye), after detailing the problem, proposed as a solution the introduction of Boys' Battalions (Sibyan Taburlari) to gradually replace Industrial Regiments (Sanayi Alayları) of conscripted soldiers. These battalions, according to the reports, would be attended by children between the ages of thirteen and nineteen, and offered an ideal solution. As the new organization would be a military school, there would be no problems with regard either to the cost of the young workers or to their obedience and discipline. Moreover, they would be employed for a fairly long time as compared to regular conscripts, particularly because, upon finishing school at age nineteen, they would be immediately conscripted into military service, thereby allowing them to be employed for another four years in the Arsenal..$^{38}$ Being a cheap, disciplined and available labor force, Boys' Battalions offered the best solution to a crucial problem facing the authorities.

Indeed, following the reports prepared for the palace, the Boys' Battalions began to recruit youngsters in 1889 . The number of recruits gradually decreased, however, and the endeavor soon failed. Indeed, during the I 897 war against Greece, all of the recruits from the Boys' Battalions were transferred to combat forces. ${ }^{39}$ Exacerbating the problem was a persistent lack of personnel even in the Industrial Regiments, from which many soldiers were either transferred to combat forces during the same war or deployed to suppress internal rebellions..$^{40}$ Once again, the government's ambitions to militarize the entire labor force were supplanted by the reality of civilian workers.

The authorities' inability and failure to militarize the Arsenal's labor force became an even more pressing issue during and after the Ottoman-Russian War of I877-1878. The war worsened the already devastated Ottoman economy, and severely impacted the daily lives of the Ottoman working classes. Sky-rocketing inflation forced the prospect of starvation on to the workers, whose challenging conditions already included difficulties in obtaining their wages. Although the Imperial Naval Arsenal had managed to decrease the number of civilian workers to around 800 , it still faced serious troubles, especially given its need to increase workers' wages and its inability to fund the additional costs such action would create for the Treasury. In trying to address these challenging conditions, the authorities once again sought ways to reduce maximally the number of workers in the Arsenal. In I 878, upon a request 
from the Naval Ministry, the palace issued a decree ensuring that wages would keep pace with inflation. This act would cost the Treasury an additional i 50,000 kuruş, to be funded by worker lay-offs. Accordingly, older workers and those with certain disabilities were to be immediately retired with compensation, along with any workers who were "unnecessary and lazy in their service". This measure would allow for much of the additional new costs to be offset by the money saved from no longer paying these workers' wages. ${ }^{4 \mathrm{I}}$ However, this proved to be yet another problem. Retirement funds were based almost entirely on cash deducted as a certain percentage from workers' wages. The workforce reductions instituted in recent years had already negatively impacted the balances of the retirement funds, due to the increasing gap between the number of retirees and the current number of workers. In short, to increase further the ranks of retirees while also reducing the number of active workers would be disastrous for retirement funds. Therefore, through the second half of 1879 , the government decided that, in addition to decreasing the number of workers (from 800 to 300 ), the rate of deductions from wages would be increased from 2 to 5 per cent. ${ }^{42}$

Although this was considered a temporary solution for the maintenance of retirement funds, the measures were not good news for the workers. It was not unusual for them to find their wages in arrears, but they were at least working in the Imperial Arsenal, where, even in the early i 870 , workers could confidently "rely on continuous employment". ${ }^{43}$ Yet, by the second half of the decade, even this proved to be no longer the case. The workers' anxieties about losing their jobs, coupled with their hitherto existing problems in obtaining their wages - all of which intensified with the onset of the crises - go far in explaining why the workers emerged as one of the most active and radical groups of the decade. It was hardly a coincidence that while the government's bureaucrats were negotiating amongst themselves about how to deal with the workers and their wages, the Arsenal workers were seeking to join this negotiation process by their own demonstrations and strikes. By the end of the I870s, workers in the Imperial Arsenal had succeeded in giving the impression that they had achieved certain collective repertoires, which they frequently employed against the authorities during these years.

Government correspondence about a collective strike in May I880 suggests how the workers of the Arsenal were conscious of the collective power evidenced in these established repertoires, and how this solidarity was perceived by the authorities as a serious threat. By the spring of I 880 ,

43. Pall Mall Gazette, "The Industrial Classes in Turkey". 
the authorities had implemented several measures in recent months that had proved to be less effective than had been desired. Having not been paid for almost fifteen months, Arsenal workers went on strike, "resolutely declaring" that they would not return to work until they were paid at least two months' wages. As they marched to several government offices, including that of the Grand Vizier, to voice their demands, they drew the attention of the palace, which asked the Naval Ministry to provide information about the reasons for the workers' actions. In response, Rasim Pasha, the Minister, reported that although the authorities had tried to appease the workers by promising to provide them with daily bread, the workers remained unconvinced and persisted in their demands. However, according to the Minister, the manner in which they were voicing their demands had become a more serious concern, and this latest incident was fairly consistent with previous such actions:

The workers, when they would like to go to the sublime offices to voice their conditions, need to do so by preparing a petition, which should be presented by a few leading members among them. Nonetheless, [the workers] have hitherto made it their custom to dare to go collectively and to create annoyance, and their current actions as well are rooted in their old customs $[\ldots] .{ }^{44}$

No matter how "old" Pasha may have thought these "customs", his words suggest that the Arsenal workers maintained a long-established commitment to a repertoire of struggle. This traditional way of struggle supposedly pointed to a different rationality among the workers, one that was outside the imposed procedures for voicing discontent via petition. The Minister's words show that the workers were quite successful in establishing an alternative channel in a collective and continuous way. In order to understand how they were able to forge a collective solidarity powerful enough to survive the crises of the i870s, and to recognize the ability that enabled them to form this solidarity along class lines without relying on any formal institutions, we need to trace the experiences of workers and their relations with the state in a historical process. This will allow us to see how this process reveals certain patterns through which the workers were able to maintain and consolidate this solidarity on the basis of class struggle.

\section{SPECTACLES OF CLASS SOLIDARITY}

Although the Ottoman economy managed to extricate itself from the deep depression of the I870s, the regular payment of wages remained a problem and appears to have been the most important catalyst underlying 
the struggles in this period. However, this observation is based on the available historical documents at our disposal, and it is likely that further research will reveal other, non-economic dimensions of these struggles. The economic problem was undeniably a major source of the workers' discontent with the government, yet there were other sources of strife as well, including ethno-religious conflicts in the 1890 s. For instance, after Armenian rebellions in Anatolia and Istanbul were suppressed in the first half of the I 890 , often by violent measures that included massacres, many Armenian workers were dismissed from their jobs in the capital. After I 895, many Armenian workers were gradually discharged from the Arsenal and from government jobs elsewhere in the city. ${ }^{45}$

Interestingly, these dismissals were immediately exploited by the government (which replaced the Armenians with Muslims, who were purportedly more loyal) and by other communities, who sought to take advantage of these events for their own benefit. For instance, the patriarch of the Assyrian community in Istanbul wrote a petition asking the government to replace the Armenian workers, "who were discharged due to their treachery and sedition", with members of the Assyrian community. ${ }^{46}$ Thus, even the relations between the Armenian workers and workers from other communities in the 1890 indicate that concerns about wages and general economic problems were not the only factor shaping the workers' relations with each other, with the larger society, and with the Ottoman state. ${ }^{47}$

How the workers' class solidarity was consolidated and reproduced through their struggle against the government's failure to pay their wages can be further understood by focusing on the workers' relations with the government. Throughout this period, the Hamidian government was effectively Janus-faced towards the working classes. On the one hand, Sultan Abdulhamid II implemented certain practices intended to reinvigorate and reconsolidate his legitimacy, which had been undermined by the crises of the 1870 s. To this end, he engaged in many philanthropic

45. The Standard, "The Armenian Question - The Powers and Turkey", 8 July i 895. According to Komatsu, 22 Armenians worked in the Arsenal in I896; Komatsu, "I 896'da Osmanlı Bahriyesi'nde Yabancılar ve Gayri Müslimler”, p. 20. Considering the dismissals, this number must have been higher prior to I 895 . Some Armenian workers had to escape abroad during these incidents. These included a retired Arsenal worker who went to Bulgaria but asked the government to continue his retirement wage. It was decided that he could receive the wages only if it was clear that he was not among "the corrupted"; BOA.A.MKT.MHM.633/2 I.

46. BOA. DH.TMIK.M.I $4 / 39$

47. This is also the case with regard to different dimensions of solidarity among the Ottoman workers. See for instance, M. Erdem Kabaday1, "Working for the State in a Factory in Istanbul: The Role of Factory Workers' Ethno-Religious and Gender Characteristics in State-Subject Interaction in the Late Ottoman Empire" (Ph.D. Ludwig Maximilian University, 2008). 
activities and other such actions targeting the welfare of the lower classes. These efforts were further maintained by increasing the use and visibility of symbolic ceremonies so as to corroborate the paternal image of the Sultan. ${ }^{4}$ However, these practices were accompanied by a series of repressive policies meant to prevent formation of any collective movements, organizations, or actions against the state. In focusing on how these policies functioned through the material relations between government and workers, it is possible to acknowledge that these policies in fact evolved into arenas where workers could adapt their collective discontent into demonstrations of class solidarity.

The most obvious way to impede workers from becoming involved in any open, collective discontent was to require and encourage them to convey their dissatisfaction and demands through "proper" channels. In fact, this was a necessary outcome of the period's continuing crisis concerning payment of wages. With the government unable to solve this problem completely, it was impossible to prevent the release of anger and frustration on the part of workers. So in order to keep the workers' unavoidable restlessness under control, the state authorities tried urging workers to convey their complaints through the proper submission of petitions - that is, having representatives present the petition, rather than doing so collectively. The petition process was not specific to either the Hamidian period or to the Ottoman Empire in general. Throughout Ottoman history, as well as the history of other societies, the practice of petitioning had been used by authorities for this same purpose, and had been likewise manipulated by lower classes. ${ }^{49}$ Ottoman authorities who wrote about the workers' collective actions often underscored the idea that, although workers had the right to appeal to government offices with their complaints and demands, they must always do so individually and by petition. Any gathering, regardless of size, for such purposes was unacceptable to the authorities.

A particularly notable example of this mentality on the part of the authorities, and the workers' resistance to it, is discussed in correspondence about a gathering of "a few hundred workers" from the Arsenal that took place in front of the Sublime Porte. The workers were protesting the decision to give them bonds in return for wages that had been

48. See Selim Deringil, The Well Protected Domains: Ideology and Legitimation of Power in the Ottoman Empire, 1876-1909 (London [etc.], 1999), and Nadir Özbek, Osmanl Imparatorluğu'nda Sosyal Devlet: Siyaset, İktidar, Meşruiyet, I876-19I4 (Istanbul, 2002).

49. See Lex Heerma van Voss, "Introduction", International Review of Social History, 46 (200I), Supplement 9, pp. I-IO. For an analysis focusing on the practice of petitioning by the Ottoman lower classes, see John Chalcraft, "Engaging the State: Peasants and Petitions in Egypt on the Eve of Colonial Rule", International Journal of Middle East Studies, 37 (2005), pp. 303-325. 
owed since the previous year. They were also complaining about not having been paid for almost six months in the current year. In his report on the event, the mayor (Sebremini) emphasized that he had strongly cautioned them against leaving their jobs, for "it would not be proper for them to attempt to make their requests by such an organized collectivity". According to the mayor, if the workers would submit their request to the Sultan by sending representatives to present it to him, it was quite obvious that their demands would be accepted. ${ }^{50}$ This reasoning did not convince the workers. A few days later, when they were offered small payments instead of full wages, they again left work, stating that they would not return until they had been sufficiently paid. This demand was not modified until the government promised to pay a month's wages. ${ }^{\text {II }}$

The policy's ineffectiveness in subsequent years led the government to take increasingly more repressive measures against workers. One favored method of blocking strikes was to arrest the presumed "leaders", "agitators", or "provocateurs" among the workers. This policy operated on the assumption that the workers would be appeased when isolated from the (supposed) leading members. However, such attempts by the government sometimes inadvertently revealed the degree of solidarity amongst the members of the working-class community in the Arsenal. In April and May of i 888, Arsenal workers launched a series of strikes and demonstrations in response to the latest non-payment of their wages. The authorities, having failed to solve the financial problem or to stop the increasing number of collective actions, arrested "the first among the agitators", one Mehmed from Eyub. Upon news of his arrest, the workers, now led by a certain Arif and a Mehmed Ali from Trabzon, "came to the police station and attempted to take Mehmed". As the correspondence notes, the police "defended" the station, and arrested Arif and Mehmed Ali. The police, although they managed to disperse the group, subsequently warned others in the government that such demonstrations, if tolerated, would not only become unmanageable but would spread to other workers. $^{52}$

With other demonstrations similarly revealing such measures to be ineffective, the Ministry, having failed to raise the necessary finance for the promised wages, now attempted to reduce the size of the workforce by discharging workers. Yet these actions prompted further resistance. In September I 893, the Ministry decided to discharge 300 workers from the Arsenal, claiming that it was unable to pay their wages. It determined to implement this decision gradually by discharging 20 workers every week

50. BOA.Y.PRK.ŞH.2/47.

5I. BOA. Y.PRK.ASK. $34 / 44$.

52. BOA.İ.DH./1078-84852, and BOA.Y.PRK.ASK./46-54. 
and encountered resistance not only from the workers, but also from senior officials who felt threatened by the proposed action. The palace learned that the workers were resolved to present a petition collectively to the Sultan on a Friday, which would mean a demonstration during the Friday Prayer Ceremony. ${ }^{53}$ Upon receiving this news, Grand Vizier Cevat Pasha dispatched a message to the palace, criticizing the Minister for resorting frequently to this sort of measure (such as discharging workers in order to stabilize the Ministry's funds), despite the fact that "[the Ministry] was allotted the largest amount of budget compared to other military offices". As the Ministry had again adopted this measure without informing the Grand Vizierate, "it [was] necessary that this action be prevented". ${ }^{44}$ Indeed, the Grand Vizier's report demonstrated that a significant degree of anxiety had been triggered by the workers' ability, through persistent collective struggles, to pose a formidable threat in response to policies detrimental to their interests.

This development compelled the authorities to consider alternative policies to ensure the workers' loyalty without antagonizing them. Concerning the material lives of the workers, the most relevant of these policies was likely the initiation of a paternalistic welfare system targeting the poor. ${ }^{55}$ The Hamidian government launched a series of institutions and practices intended not only to ameliorate the material conditions of its subjects, but also to increase their loyalty to the state. Religious days and festivals afforded ample opportunities for the state to bolster and increase its legitimacy, especially in respect of workers facing severe economic difficulties. Thus, even during the longer periods when workers' wages fell into arrears, the Sultan and the Sublime Porte made concerted efforts to make at least partial payments, which were presented as paternal gifts from the Sultan.

This policy was, in fact, partially a response to workers' increasing expectations that they would see their and their families' lives relieved of long-standing economic problems. That certain days functioned as catalysts to increase workers' expectations of the government was also a significant phenomenon in the formation of class solidarity. These religious days, festivals, and ceremonies functioned as temporal and spatial hubs wherein discontent among the workers could be mobilized against the rulers. This was especially crucial, given that political conditions did not allow for the formation of institutionalized structures by which the workers could organize. In other words, during these particular days and ceremonies, workers' anger and dissatisfaction could be channeled, via

55. See Özbek, Osmanlida Sosyal Devlet for an analysis of these policies. 
shared moments and social spaces, against a common target. Thus, during this era communal cultural practices came to function as a critical component in class formation.

In fact, despite the government frequently failing to meet these expectations, the authorities remained quite conscious of how workers would react under such circumstances. The possibility that workers' solidarity would be immediately called upon against the government was a major source of anxiety and disagreement within the bureaucracy, especially on the eve of religious days and festivals. An example of such anxiety is evident in correspondence between the Grand Vizierate, the Naval Ministry, and the Finance Ministry at the end of April i 889, a few days before Ramadan. The Naval Ministry complained that the money deposited by the Treasury for the payment of workers' wages was insufficient, emphasizing that any inability to pay the wages would lead to unease among the workers, especially at the beginning of Ramadan. The Finance Ministry responded defensively, arguing that other "urgent expenses" (concerning the military) had left the Treasury with insufficient funds and that the Naval Ministry should "handle" the situation using existing finance. However, the Naval Ministry responded forcefully on the same day, warning that "if the wages are not paid today, we will not be able to keep the workers under control". Upon this, and under pressure from the Grand Vizierate, the Finance Minister reluctantly agreed to pay the necessary amounts, even as he denounced the "threats and the vehement language" used by his fellow minister. ${ }^{56}$

Although the Naval Ministry's warnings had been interpreted as a "threat", they were hardly unjustified, as revealed by an incident two years later. Arsenal workers had again learned that their full wages would go unpaid during Ramadan, and were presented with an offer that would reduce their payments by 30 per cent. The palace was informed that Arsenal workers were "convening in groups throughout various places in order to decide upon the presentation of a petition" during the visit of Hirka-i Saadet. This ceremony, the traditional visit of the Sultan every mid-Ramadan to the Holy Mantle of the Prophet, was held as a parade to the mosque where the Mantle was preserved. ${ }^{57}$ Considered alongside the workers' repeated choice of using Friday Prayer Ceremonies for collective petitioning, this case further highlights how workers were able to utilize symbolic places and ceremonies for their own purposes. These ceremonies were originally intended to be spectacles of the Sultan's personal power, and were organized as such, but now they were sometimes subverted by the workers into spectacles of class solidarity and power. 
Therefore, it is unsurprising that religious days, festivals, and ceremonies often posed a source of uneasiness for government officials. ${ }^{58}$

The Festival of Sacrifice, another major event for Muslims, led to similar situations, evoking anxiety among officials and collective discontent among workers. In late June I 892, almost two weeks before the Festival commenced, the Naval Ministry once again requested that the palace urge the Finance Ministry to transfer the necessary sums of money to the Navy, so that workers in the Imperial Arsenal could be paid their wages before the holiday began. The correspondence emphasized the possibility that the arrival of the Festival might incite disquiet among the workers. ${ }^{59}$ Nonetheless, it appears that the government authorities were unable to solve the problem before the Festival, and, as had been expected, a strike was declared. ${ }^{60}$ The disagreement between the two ministries over how to meet the costs of the workers' wages remained unresolved throughout the following month, and thereby contributed to the continuation of the strikes. ${ }^{6}$ On the final day of July I 892, the Grand Vizier adopted a threatening tone towards the Finance Ministry, a tone that had proved effective in previous disagreements about how to pay the workers' wages. He warned the Finance Minister that the current strikes "are understood to [have] spread to the boiler shop workers, who would join the actions", and even to soldiers who had not received their pay. ${ }^{62}$ This unambiguous threat again proved influential on the Finance Ministry, which shortly thereafter transferred funds to the Navy for payment of the wages. ${ }^{63}$

That discontent in the Arsenal could rapidly spread from one group of workers to their fellows in other workshops, and thereby eventually lead to "unanimous" (bi'l ittifak) strikes, was not unusual, as evidenced by the many strikes and demonstrations during the period. However, the possibility that such dissent and anger might be transmitted to workers under military oversight was evidently a dire concern for officials. The scenario was particularly daunting, as it would entail a mutiny in a capital already troubled by the specters of the Janissaries (the traditional guards who had toppled many sultans, but who were violently abolished in I 826). In fact, as the payment crisis dragged on and the workers persisted in their struggle to counter it, such fears proved to be grounded. In the i 890 it

58. This was not unique to Muslim workers. For instance, in 1906 workers in the Cibali tobacco factory in Istanbul went on strike after not receiving their customary payments for Easter; Nacar, "Tobacco Workers in the Late Ottoman Empire", p. I 28.

59. BOA.Y.MTV.63/i 5 I.

60. BOA.BEO.35/2557; BEO.35/2563; and BEO.36/2660.

6r. BOA.BEO.40/2936.

62. BOA.BEO.4I/3074.

63. BOA.BEO.5I/375 I. 
was not just impoverished workers but also soldiers, especially those serving outside the palace, who were reported to be "reduced to such want as to beg alms from foreigners" ${ }^{64}$ Although the military forces were under strict discipline and surveillance, the ruling officials could not afford to assume that these severe problems would not lead to a mutiny in the heart of the capital.

The fear became a reality in mid-I90I, with Reuters reporting to the British newspapers that Ioo "sailor workmen" in the Naval Arsenal had attempted to demonstrate in front of the palace in Istanbul. Prior to the demonstration, they had been detained for almost a year upon conclusion of their service and their wages had long been in arrears. They came together in front of one of the gates of Arsenal and attempted to push through the doors:

The stout wooden doors resisted their efforts, and they therefore attacked the masonry, to loosen the hinges. The officer in charge of the Arsenal, finding they refused to obey his order to desist from their efforts, and fearful of the consequences if they were to get outside, turned out the guard, who were ordered to drive the mutinous workmen from the gates. A few bayonet thrusts soon quelled the disturbance, nine mutineers being more or less severely wounded. A number of arrests were subsequently effected. ${ }^{65}$

The report went on to underline the "starving" conditions of the Arsenal workers (a result of their wages being in arrears for so long), and, based on the frustrating conditions at the Treasury, to anticipate that these sorts of events would spread to other "government departments". According to the correspondent, this latest action by Arsenal workers proved effective, as the Sultan now promised "to give satisfaction to the demands of the demonstrators". ${ }^{66}$ British newspapers reported this news on 3 June, prompting the Sultan to decree that no British newspapers be allowed to enter the Empire; he also ordered that an immediate disclaimer about the event be sent to the British press. ${ }^{67}$ As such developments indicate, by the first years of the new century the crisis was understood to be chronic in nature. New measures attempted by the government towards ending the wage problem would, through the middle of the decade, continue to face seemingly unyielding resistance and would prompt yet another wave of struggles between the workers and the state.

64. Western Gazette, "Soldiers Begging Alms", 23 October I 896. Meanwhile, Ioo workers in the Arsenal went on strike, "threatening to go to" the palace, and could only be appeased by payment of a small amount of the wages in arrears; Northern Echo, "Workmen Clamour for Wages", I4 October I895, and The Star, "Situation in Turkey", Is October I 896.

65. Sheffield Daily Telegraph, "The Porte and Unpaid Workmen", 3 June I90I.

66. Ibid.

67. BOA.Y.A.HUS.416/59. 


\section{RADICALIZATION AND REVOLUTION}

By the turn of the century, it had become commonplace for workers to leave their jobs temporarily whenever they did not receive proper pay. Such actions did not necessarily involve collective demonstrations in front of a government building. In April 1904, for example, groups of Arsenal workers gathered in coffee houses around Kasımpaşa (the district in the vicinity of the Arsenal) instead of going to work, in reaction to their wages not being fully paid. Upon learning of these developments, the Sultan ordered the Naval Ministry to pay the workers their wages but to "kindly warn" them against engaging in further such activities. ${ }^{68}$ However, these sorts of actions had grown even more intolerable for the government, especially after 1905 with the emergence of a new social and economic crisis. The growing depression created by the economic crisis, and the additional taxes now being levied, spurred many antigovernment rebellions amongst local populations throughout Anatolia. Adding to the intensity of these rebellions was the increasing power and mobility of political opposition groups throughout both the Balkans and Anatolia, the most active of whom were the Young Turks and Armenian Dashnaks. ${ }^{69}$

Within this context, the tendency of workers to engage in collective actions against the government seemed to constitute a more serious potential threat in the capital, as such actions could easily be mobilized in favor of opposition groups and thereby eventually lead to the palace facing a mortal crisis. Thus, by the start of ig05, it had become clear to the government that new steps had to be taken to render this potential threat as ineffective as possible. For the officials, the most obvious such measure was to eliminate the extra labor force, which the government regarded as "unnecessary" for the Arsenal. The previous attempts to discharge workers had failed in the face of the workers' resistance, and subsequently temporary workers were, in due course, granted permanent worker status, even in the absence of immediate jobs in the Arsenal. By 1905, however, dismissing unnecessary workers from the Arsenal presented an urgent solution to the economic and social problems created by these surplus workers. Besides being an additional financial burden on an already drained Treasury, these workers were prone to appealing for collective actions to be used to convey their discontent. In this way, such workers became an increasingly valuable bedrock of support for the opposition.

However, resorting to large-scale layoffs was a double-edged sword for the government. Although the Ottoman rulers urgently wished to dismiss workers, they also feared the negative repercussions the policy posed for

69. Hanioğlu, "Preparation for a Revolution", p. 93. 
the state, especially for the palace. In the summer of 1905 , upon the Naval Ministry's request to discharge 200 workers from the Arsenal, the palace ordered that necessary financial arrangements (concerning the workers' compensation) be made by the Grand Vizierate. However, the correspondence highlighted that these workers were in fact being discharged "by their own desire". This and other similar phrases, such as "by their own will", were quickly adopted into the language of the dismissals, to reassure the palace that the workers would not create problems after their contracts were ended. In August 1905, the Grand Vizierate decided that the 200 workers, even though they were to be discharged "by their own desire", should be dismissed gradually rather than en masse, so as to prevent any occurrences of "voices and complaints". ${ }^{70}$

The palace's anxiety about the frequent strikes escalated throughout the following months, especially with the increasing amount of news about tax rebellions in Anatolia. This spurred renewed attempts within the bureaucracy to solve the chronic problem. In March 1906, as workers undertook a strike just a month after having been paid during the Festival of Sacrifice, the Sultan ordered the Naval Ministry to form a commission to discuss the measures necessary to halt the strikes, underscoring that "that these [workers] have adopted such unruly actions should be regarded as being a consequence of provocations by a few among them". Unsurprisingly, the commission, led by the Minister, determined that these latest actions had initially been instigated by nine workers. The commission expelled them, as well as twenty-three other workers identified in the reports and journals. Besides ensuring that these "provocateurs" were dismissed, the commission urged, in a report, that all remaining workers should be "kept under constant surveillance by the officials and soldiers in the workshops". The latter were to report immediately any provocateur among the workers and were to be held responsible if such disturbances reoccurred..$^{7 \mathrm{I}}$

The report also argued that, under normal circumstances, the number of workers should be doubled. The main problem preventing this was lack of "coal and other sorts of materials" necessary for operation of the workshops. ${ }^{72}$ As these sorts of shortages could not be resolved, the report urged that temporary workers not be allowed to stay permanently. More importantly, it also proposed a familiar solution: that all civilian workers be replaced by soldiers from the Industrial Regiments, who were far less

70. BOA.Y.A.HUS.49I/27, and MV.iri $/ 77$.

7I. BOA.Y.MTV.285/57

72. According to Quataert, the failure of the Ottoman government efficiently to extract the coal in the coalfields in Zonguldak had much to do with relations between the miners and the state; see D. Quataert, Miners and the State in the Ottoman Empire: The Zonguldak Coalfield I822-I920 (New York [etc.], 2006). 
expensive to employ. However, as the Industrial Regiments did not offer the necessary number of workers, the report demanded that the regiments employ 450 soldiers from the army, as a temporary solution. In this way, the rest of the workers in the Arsenal, having been purged of the provocateurs amongst them, would be reduced numerically and kept under constant supervision. ${ }^{73}$

By 1907, however, the state's chronic problems in financing workers' wages, as well as the smoldering threat posed by unpaid workers, still persisted. In fact, this year saw the government's financial problems intensify severely, thanks to eruption of a new global financial crisis. The palace, however, still fearful of triggering collective disobedience, did not wish to antagonize workers by such dismissals. Indeed, besides not dismissing the workers, the palace was also pressing the ministries to make the workers' payments as regularly as possible. Throughout the correspondence regarding these payments, an underlining concern was "the tendency of workers to begin complaining as the payment day draws closer", especially when payment was delayed. ${ }^{74}$ Thus, despite the negotiations within the bureaucracy towards solving this problem at the workers' expense, the palace appears to have yielded to the workers' demands and accepted their irreplaceability. The Sultan, mindful of how powerful and effective the workers' solidarity could be in creating further problems in the capital, opted not to take any measures at their expense.

Eventually, however, this generally passive stance towards the workers drew reactions from the Sublime Porte, who had to act under constant pressure from the palace not only to ensure that workers did not pose security problems, but also to fund their wages during the current poor economic conditions. In May 1907, after the Arsenal workers again went on strike, and subsequently received a set amount of money thanks to pressure from the palace, the Grand Vizier opted to convey to the palace the impatience of the bureaucracy. He prepared a report complaining about the palace's passive attitude towards the workers:

There are no naval constructions in the Arsenal whatsoever, and so it is not fathomable why so many workers remain employed there and are paid continuously. Against the urgent recommendations that they should be released, and preferably expelled and returned to their homelands, various objections have been put forth that are impossible to be acknowledged by their humble servants. Yet the problems emanate from the fact that the treasury is continuously hindered in providing for their financial sustenance and that the workers frequently stand up to make such demands by coming together collectively. And these problems have significance beyond any consideration $[\ldots] .^{75}$ 
A few days after receiving the Grand Vizier's report, which warned the palace to take "urgent" measures to solve the problem in question, the Sultan questioned the Naval Minister about his views on the subject. The Minister bemoaned the Grand Vizier's indifference towards solving the problems of his ministry, but also confirmed the damages that unnecessary workers created for the Treasury. ${ }^{76}$

Following this correspondence, the Sultan was finally convinced of the need for dismissals; thirty-five workers were discharged "by their own will" from the Arsenal the same week. However, the Minister was acutely aware that formulations like "their own will" were mere rhetoric, and he urged the Ministry of the Police to ensure that the discharged workers "would not raise subsequent complaints or apply to rejoin the workers of the Imperial Arsenal". ${ }^{77}$ This anxiety about the workers' possible reactions proved correct just days later. The workers who had departed the Arsenal "by their own desire" now assembled and attempted to enter the Arsenal, with the intention of working on the maintenance of a recently arrived Russian ship. This action posed such a serious threat to future plans to discharge additional workers that the Naval Minister urged the palace to warn the Ministry of the Police immediately to halt these attempts. Otherwise, warned the Minister, "[workers'] current actions would cripple the attempt" to balance the budget necessary for regular payment of wages in the Arsenal. ${ }^{78}$

However, the remaining workers continued their protests throughout the payment period; ${ }^{79}$ the government then adopted more repressive measures, which further antagonized the workers. A month later, the government arrested nine workers accused of striking and inciting others to do likewise. Following these arrests, the rest of the workers joined together and "declared that they would not go to work unless the mentioned workers be released" ${ }^{8 \circ}$ Two days later "more than a thousand Arsenal workers" marched to Beşiktaş, site of the palace. ${ }^{8 \mathrm{I}}$ This appears to have been one of the largest protests the capital had seen in recent years, and it demonstrated the acute and widespread resentment that had arisen over the dismissals and the payment crises. Nevertheless, the palace was resolved not only to expel the arrested workers, but also to keep them under constant surveillance in whatever cities they were to be expelled to. On 24 June, a message was sent to five provinces, warning the governors that these workers had been expelled for industrial agitation

\footnotetext{
76. BOA.Y.MTV.298/9.

77. BOA.ZB.I6/I I.

78. BOA.Y.MTV.298/47.

79. See BOA.I.HUS.I $55 / 1325$ Ca4.

80. BOA.ZB.r6/is.

8I. BOA.Y.PRK.ASK.248/46.
} 
and thus "must not be allowed to move outside the provinces, or back to" the capital. ${ }^{82}$

The subsequent course of relations between the palace and the Arsenal workers makes clear that the palace was growing increasingly less tolerant of the workers and was now ardently resolved to clear the workers of "agitators" after each strike. ${ }^{83}$ However, these measures proved ineffective in stopping the workers. On 8 March 1908, the Arsenal workers convened "again" in an attempt to march to the palace. ${ }^{84}$ Four days later, the Sultan ordered that the agitators and provocateurs amongst them be banished from the capital. He also cautioned against any further disorder from other workers while their friends were being expelled. ${ }^{85}$ The government continued to discharge workers, and there were no optimistic signs of any permanent solution or easing of tensions in the Arsenal. In mid-June I908, the authorities were even "trying to reassure the soldiers" in the Arsenal, who had expressed discontent upon not being paid their full wages. ${ }^{86}$

The Declaration of Liberty in 1908 following the Young Turks' rebellion in the Balkans thus found an already antagonized and radicalized community of workers in the Imperial Naval Arsenal in Istanbul. Immediately after the Declaration, the working classes of the Ottoman Empire sought to put their own mark on the revolution by launching a spontaneous wave of strikes. They were joined in the following months by thousands of workers from throughout the Empire, including those in the Arsenal. ${ }^{87}$

Both the active and the recently dismissed Arsenal workers attempted to benefit from the revolution by exerting their own collective power. On the day that newspapers first announced the Declaration of Liberty, fiftysix workers who had previously been dismissed appealed to the Naval Ministry; they were reinstated the same day. However, according to a petition they presented two weeks later, they were subsequently discharged yet again, this time due to an alleged procedural problem. According to the petition, this justification was a pretense, as they were soon replaced by new "unqualified" workers. Although the Ministry, in the ensuing correspondence, denied the latter allegation, it admitted that

82. BOA.ZB.439/29 and BOA.ZB.453/60.

83. BOA.ZB.r6/26 and ZB.39I/3I. Meanwhile, children working in the rolling mill went on strike, owing to their resentment of the director and his deputy. Immediately after the strike, the Naval Minister ordered that both officials be replaced "immediately"; BOA.Y.PRK.ASK.248/103.

84. BOA.İ.HUS.I $64 / \mathrm{I} 326-\mathrm{S} / \mathrm{I} 2$.

85. BOA.I.HUS.164/1 $326-S / 16$, and BOA. ZB.313/r.

86. BOA.Y.PRK.BŞK. $78 / 99$.

87. Șehmus Güzel, “Tanzimat'tan Cumhuriyet'e İşçi Hareketleri ve Grevler”, Tanzimat'tan Cumburiyet'e Türkiye Ansiklopedisi, 3 (1985), pp. 803-828, 8 I4. 
the workers had indeed been discharged and that the remaining workers would be dismissed gradually over the following weeks. ${ }^{88}$

The workers' petition offers important clues about how they perceived the new process. They welcomed the Declaration and the reinstatement of the Constitution as a new era and a chance to return to their jobs, even as they emphasized how they and their families had been suffering from hunger and poverty due to being left unemployed. They also noted that they had presented "thousands of petitions" to demand their jobs back. The rhetoric employed throughout this particular petition suggests that the workers had quickly adopted the revolutionary discourse and were now appropriating it so as to serve their own goals:

We are humbly grateful to our Sultan and the Society of Union and Progress of the Nation [sic] who, by divine truth, granted the liberty and justice to the nation [when] our loyal services of thirty to forty years were trampled and [we were] left in misery. Your worker subjects, who remained under that dark smoke in the Era of Tyranny, today attained the shining sun of liberty and happiness $[\ldots]$.

In the rest of the petition, the workers addressed the Grand Vizier, requesting that he put an end to this situation, on the basis of "the incompatibility of this situation to justice and liberty as endowed by the Constitution to the noble Ottoman nation". The frequent use of revolutionary slogans like "liberty" and "justice", the deliberate references to the "Ottoman nation" and the "Constitution", and the depiction of the previous era as having been "the Era of Tyranny" mirrored the rhetoric of the Unionists. In short, the Declaration of Liberty opened a new space in which they could continue their struggles against the Ottoman authorities. The workers demonstrated that they were keenly aware of this new reality: they took action on the first day of the revolution, and embraced the discourse that came with it. ${ }^{89}$

88. BOA.BEO. $3380 / 253454$.

89. It is striking that in this petition the workers preferred the term işçi for themselves rather than the more common word amele. Both words had the same meaning and were used interchangeably in the late Ottoman Empire, but use of işçi would increase, especially after the revolution. The main reason was probably the connotations of the word amele in Turkish, which associated the term with less skilled laborers, sometimes in a derogatory way. Indeed,

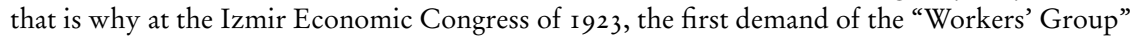
was the replacement of amele with işçi in official documents. However, this did not mean an abrupt transition from amele to $i s ̧ c ̧ i$, as proven by another petition handed in a few weeks later, which uses amele. Indeed, leftist organizations and publications would continue to use both terms until the republican period. For more details on this, see Feroz Ahmad, "The Development of Working-Class Consciousness in Turkey", in Zachary Lockman (ed.), Workers and Working Classes in the Middle East: Struggles, Histories, Historiographies (Albany, NY, 1994), pp. I33-I64. Of course the scarcity of original petitions from the previous era keeps us from making any clear-cut arguments, but this insistent use of $i s ̧ c ̧ i$ in the same petition, side by side 
This rhetoric's effectiveness seems to have fallen short in returning the workers to their jobs, for several more collective petitions were submitted requesting re-employment in the Arsenal. As the demands were not met, the language of these petitions became increasingly severe against the government. One of the petitions to the Ministry of the Interior starkly demonstrates the extent to which these former workers had become radicalized against the state. The petitioners implicitly and even explicitly threatened the authorities, by forcefully emphasizing that they and their families were "starving":

As your Excellency is aware, every evil stems from hunger. Theft and murder as well are born of hunger. Please, at least until a job opens for us at the Arsenal, give us daily bread, such that you can cut from our wages when we begin working again. Otherwise, we will dare to seize and take the bread coming from public bakeries in the Arsenal. For our state is our father and mother. We are not the subjects of any other state. We are the slaves of our state and our nation..$^{\circ}$

Although the available documents do not show that this threat was acted upon, the language deployed by the workers demonstrates not only how they were able to manipulate the widely used rhetoric of "nation" and "state" on their own behalf (the press, for example, abounded with such expressions after the revolution). It also illustrates that they were confident that relying on their solidarity and collective power would allow them to compel and even threaten the state. Indeed, various correspondences concerning this petition reveal that officials were acutely anxious about this sort of language. They called upon the Naval Ministry to find and implement alternative ways to appease the workers, short of returning them to work. ${ }^{9 \mathrm{I}}$

\section{CONCLUSION}

The Revolution of 1908 was not simply a declaration enforced by the rebellions of a small group of army officers, organized under the Committee of Union and Progress. Immediately after the Declaration of Liberty in July 1908, millions of people throughout the Empire transformed the event into a revolution by means of their own collective initiatives. In order to understand the revolutionary process in 1908 one must take into account the involvement of ordinary people. It was a

with other revolutionary terminology, suggests that workers might have used the word as part of the new vocabulary they adopted after the revolution.

90. BOA.DH.MKT.2623/3.

9I. BOA.DH.MKT.r295/57, and BOA.DH.MKT.26I6/2I. Nevertheless, the government continued dismissing workers, leading to strikes and other collective actions throughout the following year. For examples, see BOA.BEO.3671/275255 and BOA.ZB.332/18. 
revolution not simply because the Sultan submitted to the demands of the officers, but also because the collective practices of Ottoman society claimed this historic moment for themselves and converted it into a revolutionary process.

The question then should be pointed towards the very processes of politicization and radicalization that allowed for immediate adoption of the Declaration of Liberty in Ottoman society, especially among the working classes who played a prominent role in this transformation. One way to acknowledge the workers' sympathy for the new regime is to look at the preceding decades of discontent against Hamidian rule. Further examination of this history through various other cases involving Ottoman workers will, as this article has demonstrated, help to pinpoint the links between class formation among Ottoman workers and the Revolution of 1908. Such analysis will reveal the extent to which the revolution can be described as an intersection of various processes of class formation and radicalization against the Ottoman government. It will, thus, facilitate more effective understanding of the class dimensions of this process, which remains insufficiently considered in the historiography of the revolution.

However, it should not be concluded from the cases discussed here that discontent over wages was the only channel of antagonism for Ottoman workers. As noted, future research into the everyday experiences and non-class identities and relations of workers (i.e. ethnicity, religion, and gender) promises to contribute valuable insights into how these identities functioned in the Ottoman context and how they may have solidified, cross-cut, and/or weakened class solidarity. These inquiries may also reveal how different ideas/ideologies, including those of the Young Turks and the Dashnaks, influenced the process of politicization against the regime. ${ }^{92}$ The narrative above has attempted to detail how the making of this radicalization can be identified and understood by considering the workers' relations with and struggles against the state. Research into the experiences of other working-class communities in the Empire will allow for revising the dominant narrative with regard to the revolution, especially by widening the exclusive focus on the Young Turks so as to include the central role of working classes in the history of the revolution.

92. In fact, according to Quataert, Young Turk agitation had a primary influence on the machine-breaking events in western Anatolia prior to the revolution; see Quataert, "MachineBreaking and the Changing Carpet Industry". Young Turks, however, did not have a monopoly on the agitation of working classes. For an examination of the role of radical leftist ideas and networks in the collective actions of the workers in Beirut, Alexandria, and Cairo in this era, see Ilham Khuri-Makdisi, The Eastern Mediterranean and the Making of Global Radicalism, I860-I9I4 (Berkeley, CA, 20I0). 


\author{
TRANSLATED ABSTRACTS \\ FRENCH - GERMAN - SPANISH
}

\begin{abstract}
Akın Sefer. De la solidarité de classe à la révolution: la radicalisation des travailleurs d'arsenal dans l'empire ottoman tardif.
\end{abstract}

Cet article place dans une perspective ascendante l'histoire de la révolution de 1908 dans l'Empire ottoman, en se concentrant sur l'expérience des travailleurs dans l'Arsenal naval impérial (Tersâne-i Âmire) à Istanbul. S'inspirant principalement de documents fondamentaux, il examine les luttes et les relations des travailleurs de l'Arsenal de la seconde moitié du dix-neuvième siècle à la révolution, dans la perspective d'une formation de classe. L'intervention des travailleurs de l'Arsenal dans la révolution s'enracina dans leur solidarité de classe qui se révéla de différentes façons tout au long de cette période. Ce qui incita les travailleurs à embrasser immédiatement la révolution fut leur radicalisation contre l'État qui manquait à résoudre leurs problèmes économiques persistants et tentait de les renvoyer et remplacer par de la main-d'œuvre militaire. Le cas des travailleurs de l'arsenal souligne donc le rôle du mécontentement des classes ouvrières dans l'histoire de la révolution, dimension qui était restée inexplorée dans l'historiographie ottomane.

\title{
Traduction: Christine Krätke-Plard
}

\section{Akın Sefer. Von der Klassensolidarität zur Revolution: Die Radikalisierung der Zeughausarbeiter im späten osmanischen Reich}

Dieser Artikel betrachtet die Geschichte der I908 im osmanischen Reich ausgebrochenen Revolution "von unten", indem er sich auf die Erfahrungen der Arbeiter in den osmanischen Marine-Zeughäusern (Tersâne-i Âmire) in Istanbul konzentriert. Es wird überwiegend auf Primärquellen zurückgegriffen, um die Kämpfe und Verhältnisse der Zeughausarbeiter zwischen der zweiten Hälfte des I9. Jahrhunderts und bis zur Revolution aus der Perspektive der Klassenformierung zu untersuchen. Die Beteiligung der Zeughausarbeiter an der Revolution war in ihrer Klassensolidarität verwurzelt, die in diesem Zeitraum auf vielfältige Weise zum Ausdruck kam. Was die Zeughausarbeiter veranlasste, die Revolution sofort zu begrüßen, war ihre Radikalisierung gegenüber dem Staat, der nicht in der Lage war, ihre anhaltenden wirtschaftlichen Probleme zu lösen und der versuchte, sie zu entlassen und durch militärische Arbeitskräfte zu ersetzen. Der Fall der Zeughausarbeiter verweist also auf die Rolle, die die Unzufriedenheit der Arbeiter innerhalb der Revolution gespielt hat: ein Aspekt, der in der Historiografie des osmanischen Reiches bislang unterbelichtet geblieben ist.

Übersetzung: Max Henninger

Akın Sefer. De la solidaridad de clase a la revolución: la radicalización de los trabajadores de los arsenales al final del Imperio Otoman

Este artículo plantea una perspectiva desde debajo de la historia de la Revolución de 1908 en el Imperio Otomano centrándose principalmente en las experiencias de 
los trabajadores del Arsenal Naval Imperial (Tersâne-i Âmire) en Estambul. Sustentándose fundamentalmente en fuentes primarias explora las luchas y las relaciones de los trabajadores del arsenal desde la segunda mitad del siglo XIX hasta la Revolución desde una perspectiva de formación de clase. La implicación de los trabajadores del arsenal en la Revolución tiene su arraigo en la solidaridad de clase que se hizo patente de muy diferentes formas a lo largo de este periodo. Lo que les empujó a participar de forma temprana en la Revolución fue su radicalización contra el Estado que fracasaba a la hora de resolver sus problemas económicos persistentes e intentaba despedirles y reemplazarles por mano de obra procedente del estamento militar. El caso de los trabajadores del arsenal apunta al papel del descontento de la clase obrera en la historia de la Revolución, una dimensión que ha sido poco estudiada en la historiografía otomana.

Traducción: Vicent Sanz Rozalén 